\title{
Front Matter: Volume 10645
}

, "Front Matter: Volume 10645," Proc. SPIE 10645, Geospatial Informatics, Motion Imagery, and Network Analytics VIII, 1064501 (11 June 2018); doi: $10.1117 / 12.2501429$

SPIE. Event: SPIE Defense + Security, 2018, Orlando, FL, United States 


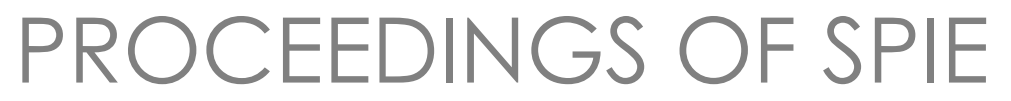

\title{
Geospatial Informatics, Motion Imagery, and Network Analytics VIII
}

\author{
Kannappan Palaniappan \\ Peter J. Doucette \\ Gunasekaran Seetharaman \\ Editors
}

16-17 April 2018

Orlando, Florida, United States

Sponsored and Published by

SPIE 
The papers in this volume were part of the technical conference cited on the cover and title page. Papers were selected and subject to review by the editors and conference program committee. Some conference presentations may not be available for publication. Additional papers and presentation recordings may be available online in the SPIE Digital Library at SPIEDigitalLibrary.org.

The papers reflect the work and thoughts of the authors and are published herein as submitted. The publisher is not responsible for the validity of the information or for any outcomes resulting from reliance thereon.

Please use the following format to cite material from these proceedings:

Author(s), "Title of Paper," in Geospatial Informatics, Motion Imagery, and Network Analytics VIII, edited by Kannappan Palaniappan, Peter J. Doucette, Gunasekaran Seetharaman, Proceedings of SPIE Vol. 10645 (SPIE, Bellingham, WA, 2018) Seven-digit Article CID Number.

ISSN: 0277-786X

ISSN: 1996-756X (electronic)

ISBN: 9781510618015

ISBN: 9781510618022 (electronic)

Published by

SPIE

P.O. Box 10, Bellingham, Washington 98227-0010 USA

Telephone +1 3606763290 (Pacific Time) · Fax +1 3606471445

SPIE.org

Copyright (C) 2018, Society of Photo-Optical Instrumentation Engineers.

Copying of material in this book for internal or personal use, or for the internal or personal use of specific clients, beyond the fair use provisions granted by the U.S. Copyright Law is authorized by SPIE subject to payment of copying fees. The Transactional Reporting Service base fee for this volume is $\$ 18.00$ per article (or portion thereof), which should be paid directly to the Copyright Clearance Center (CCC), 222 Rosewood Drive, Danvers, MA 01923. Payment may also be made electronically through CCC Online at copyright.com. Other copying for republication, resale, advertising or promotion, or any form of systematic or multiple reproduction of any material in this book is prohibited except with permission in writing from the publisher. The CCC fee code is 0277 $786 \mathrm{X} / 18 / \$ 18.00$.

Printed in the United States of America.

Publication of record for individual papers is online in the SPIE Digital Library.

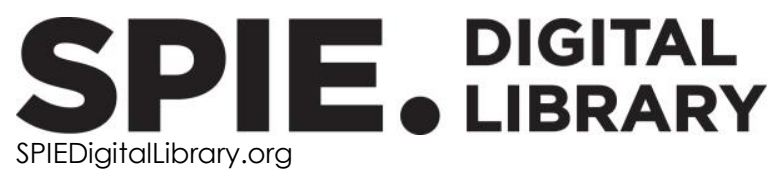

Paper Numbering: Proceedings of SPIE follow an e-First publication model. A unique citation identifier (CID) number is assigned to each article at the time of publication. Utilization of CIDs allows articles to be fully citable as soon as they are published online, and connects the same identifier to all online and print versions of the publication. SPIE uses a seven-digit CID article numbering system structured as follows:

- The first five digits correspond to the SPIE volume number.

- The last two digits indicate publication order within the volume using a Base 36 numbering system employing both numerals and letters. These two-number sets start with $00,01,02,03,04$, $05,06,07,08,09,0 A, 0 B \ldots$ OZ, followed by 10-1Z, 20-2Z, etc. The CID Number appears on each page of the manuscript. 


\title{
Contents
}

\author{
$\checkmark \quad$ Authors \\ vii Conference Committee
}

GEOSPATIAL ANALYTICS I

1064502 Ground vehicle power line spectral sensing using GIS [10645-1]

1064503 Urban 3D challenge: building footprint detection using orthorectified imagery and digital surface models from commercial satellites [10645-2]

1064504 Quadcopter sensing of magnetic and electric fields with geospatial analytics [10645-3]

GEOSPATIAL ANALYTICS II

1064505 Tailoring image compression to mission needs: predicting NIIRS loss due to image compression [10645-5]

1064506 Feasibility of an interpretability metric for LIDAR data [10645-6]

1064507 Leveraging synthetic imagery for collision-at-sea avoidance [10645-7]

MOTION IMAGERY ANALYTICS

1064508 Learning a dictionary of activities from motion imagery tracking data [10645-8]

1064509 Motion image data collection simulation for structure-from-motion 3D target reconstruction [10645-9]

$10645 \mathrm{OA} \quad$ Aggregating motion and image quality metrics for video quality assessment [10645-10]

$10645 \mathrm{OB}$ A hybrid local and global multi-object tracking with semantic spatial and appearance modules [10645-11] 


\section{GEOLOCATION AND REGISTRATION}

10645 OC Geolocation system estimators: processes for their quality assurance and quality control [10645-12]

10645 OD Targeted 3D modeling from UAV imagery [10645-13]

10645 OE Verifying the predicted uncertainty of Bayesian estimators [10645-14]

10645 OF An investigation into strategies to improve optical flow on degraded data [10645-15]

10645 OG Evaluation of different image processing methods in the context of an image registration workflow [10645-16]

$10645 \mathrm{OH}$ Real-time geoprojection and stabilization on airborne GPU-enabled embedded systems [10645-17]

\section{POSTER SESSION}

10645 ol Geospatial content summarization of UAV aerial imagery using mosaicking [10645-18]

$10645 \mathrm{0J}$ Evaluation of feature matching in aerial imagery for structure-from motion and bundle adjustment [10645-19]

10645 OK 3D patch-based multi-view stereo for high-resolution imagery [10645-20]

$10645 \mathrm{OL} \quad$ Robust target tracking using adaptive color feature and likelihood fusion [10645-21] 


\section{Authors}

Numbers in the index correspond to the last two digits of the seven-digit citation identifier (CID) article numbering system used in Proceedings of SPIE. The first five digits reflect the volume number. Base 36 numbering is employed for the last two digits and indicates the order of articles within the volume. Numbers start with 00, 01, 02, 03, 04, 05, 06, 07, 08, 09, OA, OB...0Z, followed by 10-1Z, 20-2Z, etc.

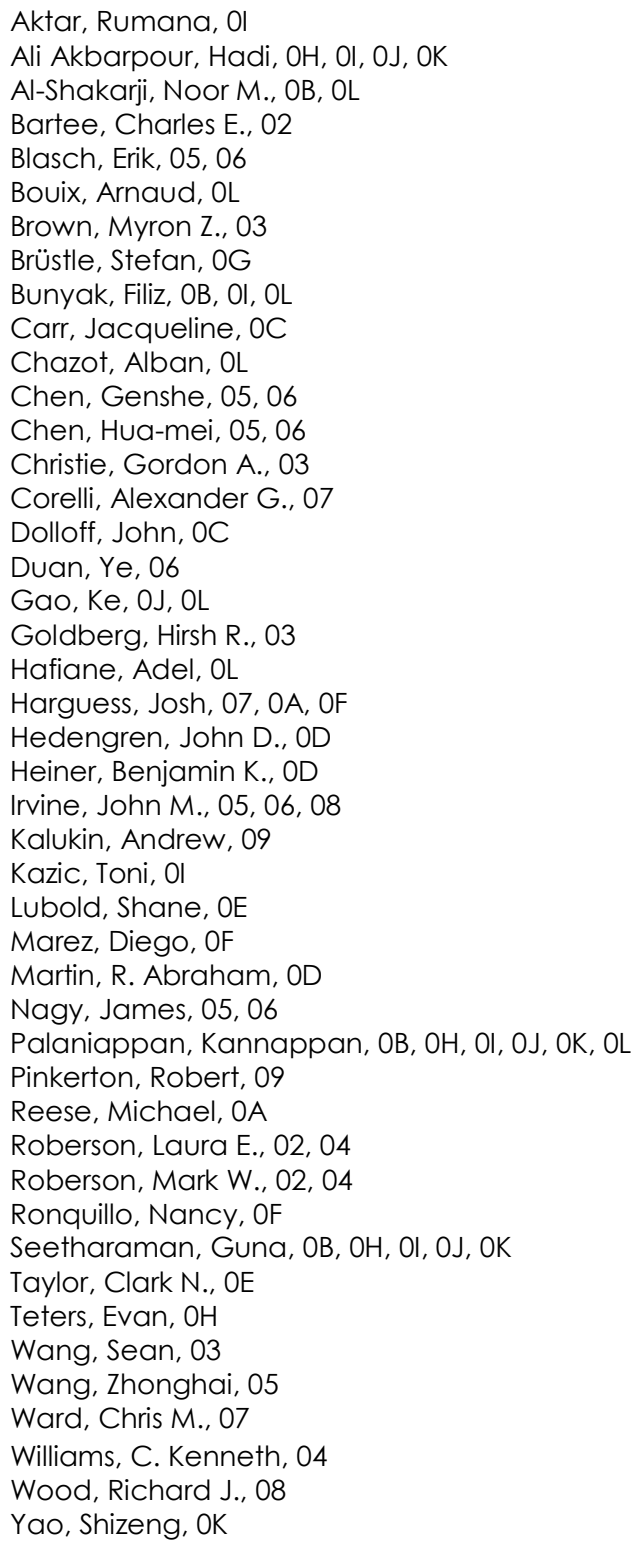


Proc. of SPIE Vol. 10645 1064501-6

Downloaded From: https://www.spiedigitallibrary.org/conference-proceedings-of-spie on 26 Apr 2023 Terms of Use: https://www.spiedigitallibrary.org/terms-of-use 


\section{Conference Committee}

Symposium Chair

Arthur A. Morrish, Raytheon Space and Airborne Systems

(United States)

Symposium Co-chair

Ruth L. Moser, Air Force Research Laboratory (United States)

Conference Chairs

Kannappan Palaniappan, University of Missouri-Columbia (United States)

Peter J. Doucette, U.S. Geological Survey (United States)

Gunasekaran Seetharaman, U.S. Naval Research Laboratory (United States)

Conference Program Committee

Alex Aved, Air Force Research Laboratory (United States)

John A. Berger, Toyon Research Corporation (United States)

Subhasis Chaudhuri, Indian Institute of Technology Bombay (India)

Ananda Shankar Chowdhury, Jadavpur University (India)

John T. Dolloff, Integrity Applications, Inc. (United States)

Joshua D. Harguess, SPAWAR Systems Center Pacific (United States)

Jutta E. Hild, Fraunhofer-Institut für Optronik, Systemtechnik und Bildauswertung (Germany)

John M. Irvine, Draper Laboratory (United States)

Stefan R. Jaeger, National Library of Medicine (United States)

Simon J. Julier, University College London (United Kingdom)

Chandra Kambhamettu, University of Delaware (United States)

Ross Maciejewski, Arizona State University (United States)

Richard J. Maude, University of Oxford (United Kingdom)

Upesh Patel, U.S. Army Communications-Electronics Command (United States)

V. B. Surya Prasath, University of Missouri-Columbia (United States)

Bruce Quirk, U.S. Geological Survey (United States)

Sartaj Sahni, University of Florida (United States)

Carl Salvaggio, Rochester Institute of Technology (United States)

Stefano Soatto, University of California, Los Angeles (United States)

Clark N. Taylor, Air Force Research Laboratory (United States) 
William R. Thissell, Chenega Technical Innovations, LLC (United States)

Jonathan D. Tucker, Lockheed Martin Corporation (United States) Zhuoting Wu, U.S. Geological Survey (United States) 